MILAN VUJANIĆ, Ph.D. ${ }^{1}$

E-mail: m.vujanic@sf.bg.ac.rs

BORIS ANTIĆ, Ph.D. ${ }^{1}$

E-mail: b.antic@sf.bg.ac.rs

DALIBOR PEŠIć, Ph.D. ${ }^{1}$

E-mail: d.pesic@sf.bg.ac.rs

MILAN SAVIĆEVIĆ, M.Sc. ${ }^{1}$

(Corresponding author)

E-mail: milan_savicevic@yahoo.com

${ }^{1}$ University of Belgrade,

Faculty of Transport and Traffic Engineering

Vojvode Stepe 305, 11000 Belgrade, Serbia
Safety and Security in Traffic Review

Submitted: May 30, 2015

Accepted: Aug. 15, 2016

\title{
SAFETY EFFECTIVENESS OF CONVERTING CONVENTIONAL INTERSECTIONS TO ROUNDABOUTS: CASE STUDY IN THE CITY OF NIŠ
}

\begin{abstract}
Intersections present a big safety problem in traffic since there has been an increased risk of crashes because of conflicts in the flows intersecting. A great number of studies done in the world show that roundabouts are safer than conventional intersections since it has been recorded that after the conversion to roundabouts the number of crashes has been decreasing. The research on applying Empirical Bayes (EB) method has been conducted by using 15 two-lane intersections in the city of Niš (Serbia), which have been converted into large compact two-lane roundabouts during the period of 2005-2013. The results show that the conversion of conventional intersections into roundabouts has positive effect on reducing the number of crashes. For all intersections, the reduction of crashes is estimated at around $76 \%$ for all crashes, i.e. $80 \%$ for the crashes with injuries. For different groups of intersections the effects are determined separately.
\end{abstract}

\section{KEY WORDS}

traffic safety effectiveness; roundabouts; Empirical Bayes method;

\section{INTRODUCTION}

Intersections safety is a serious safety concern worldwide [1]. Serbia is also in a similar predicament, where 7,050 crashes happened at intersections in urban areas, and where there were 54 fatalities, and 4,024 slightly or severely injured in 2012 [2]. There is a general consensus that roundabouts are safer than conventional intersections, so in many countries it is common practice to build different types of roundabouts. In countries where roundabouts were not typically built in the past (like in Serbia), these types of intersections are becoming increasingly popular [3-8].
After the adoption of new laws in the field of traffic infrastructure in 2005, in Serbia many conventional intersections were converted into roundabouts. There are no precise data how many conventional intersections have been converted into roundabouts in Serbia, but their number is constantly increasing [2]. Also, there are no precise data as to how much safer roundabouts are in Serbia in comparison to conventional ones.

The increased safety of roundabouts occurs as a result of reducing the number of conflict points compared to conventional intersections, slower speed when entering, and throughout intersections, which also makes roundabouts safer for pedestrians [1518]. Reducing the number of conflict points is related primarily to the conflicts between vehicles [19] [20].

Numerous studies have shown that roundabouts are much safer than conventional intersections in terms of the decreased number of crashes that have been recorded, as well as the number of the injured [9-14]. Some of these studies used an Empirical Bayes (EB) method for observational studies before and after as well as meta-analysis or naive before-after analysis for determination of safety effectiveness of conventional intersections to roundabouts. Table 1 shows that different studies indicate a decrease in the number of crashes at roundabouts, but they also show different effects in decreasing the number of vehicle-to-vehicle crashes. Effectiveness of roundabouts concerning traffic safety depends on a variety of factors such as: design geometry, number of traffic lanes, speed limit, participation of pedestrians and cyclists in traffic, and history of roundabouts in a region, i.e. the familiarity of drivers with the roundabouts $[12,14]$. 
M. Vujanić, et al.: Safety Effectiveness of Converting Conventional Intersections to Roundabouts: Case Study in the City of Niš

Table 1 - Safety results regarding converting intersections to roundabouts

\begin{tabular}{||c|c|c||}
\hline Authors & Reduction related to & Overall reduction \\
\hline \hline Schoon and Van Minnen (1993) [9] & & $-47 \%$ \\
\hline ITE (1999) [10] & & $-15 \%$ \\
\hline Hyden and Varhelyi (2000) [11] & & $-46 \%$ \\
\hline \multirow{2}{*}{ Persaud et al. (2001) [12] } & all crashes & $-39 \%$ \\
\cline { 2 - 3 } & crashes with injured & $-76 \%$ \\
\hline Elvik (2003) [13] & crashes with injured & from -30\% to -50\% \\
\hline De Brabander and Vereeck (2007) [14] & crashes with injured & $-39 \%$ \\
\hline \multirow{3}{*}{ Rodegerdts et al. (2010) [4] } & Australia (all crashes) & from -41\% to -61\% \\
\cline { 2 - 3 } & Australia (injury crashes) & from -45\% to -87\% \\
\cline { 2 - 3 } & France (injury crashes) & from -57\% to -78\% \\
\cline { 2 - 3 } & Germany (all crashes) & $-36 \%$ \\
\cline { 2 - 3 } & Netherlands (all crashes) & $-47 \%$ \\
\cline { 2 - 3 } & UK (injury crashes) & from -25\% to -39\% \\
\cline { 2 - 3 } & USA (all crashes) & $-35 \%$ \\
\cline { 2 - 3 } & USA (injury crashes) & $-76 \%$ \\
\hline \multirow{2}{*}{ Gross et al. (2013) [1] } & all crashes & $-21 \%$ \\
\cline { 2 - 3 } & crashes with injured & $-66 \%$ \\
\hline
\end{tabular}

Although a constant growth of newly built large compact two-lane roundabouts has been recorded in Serbia since 2005 [2], the safety effect of roundabouts is essentially unknown. Here, research results on the safety effectiveness of roundabouts are presented based on the example of 15 two-lane entry/exit intersections in the city of Niš. All converted intersections were two-lane so it was impossible to question the effectiveness of conversion for one-lane intersections, at which as shown in many studies, the conversion has better effects in terms of decreasing the crash number $[12,1]$. In general, double-lane roundabouts have some of the same safety performance characteristics as their simpler single-lane counterparts. However, due to the presence of additional entry lanes and the accompanying need to provide wider circulatory and exit roadways, double lane roundabouts introduce additional conflicts not present in single-lane roundabouts. This makes it important to use the minimum required number of entry, circulating and exit lanes, subject to capacity considerations [4]. For example, according to United Kingdom roundabout crash models, for 10,000 entering AADT, flaring the entry width from one to two lanes is likely to increase injury crashes by 25 percent [29].

\section{METHODOLOGY}

To determine the safety effects of replacing conventional intersections with roundabouts, the city of Nis has been used as an example to illustrate the situation where 15 intersections were replaced by large compact [33] two-lane roundabouts from 2005 to
2013. These intersections were chosen for conversion by Land Development Public Agency in Niš for several reasons, but firstly because of safety concerns. On intersections with a high number of crashes, which were identified as black spots, marked as $\mathrm{E}, \mathrm{M}$ and $\mathrm{N}$ (Table 2), the conversion was conducted as a rehabilitation measure. On others, the building of roundabouts was for the purpose of traffic calming. The main aim of these conversions was to reduce vehicle-to-vehicle conflict points, but also to reduce vehicle speeds in terms of improving vehicle safety as well as safety of vulnerable road users.

Data on traffic accidents which are used here were provided by the Serbian Ministry of the Interior. The Serbian Ministry of the Interior has a comprehensive database (a very large quantity of data on all reported traffic accidents) with adequate accuracy. Data on dates of roundabout construction, as well as all estimated AADT (Average Annual Daily Traffic) were obtained from the Land Development Public Agency in Niš, which periodically organizes the traffic counting for different project purposes.

To determine the safety effects of replacing conventional intersections with roundabouts, the EB method for observational studies before and after as in [21] is used. By using EB evaluation, the changes in traffic safety for a certain type of crashes at the intersections which have been converted into roundabouts are calculated by Equations 1 and 2, where $\pi$ is an expected number of crashes which would typically happen at intersections in the period after conversion if the intersections were not converted into roundabouts (estimated by using the EB procedure), and $\lambda$ is a 
M. Vujanić, et al.: Safety Effectiveness of Converting Conventional Intersections to Roundabouts: Case Study in the City of Niš

Table 2 - Intersection data

\begin{tabular}{|c|c|c|c|c|c|c|c|c|c|c|c|c|c|}
\hline \multirow{3}{*}{ 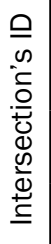 } & \multirow{3}{*}{ 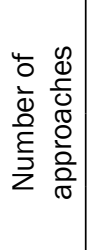 } & \multirow{3}{*}{$\begin{array}{c}\text { Controlled } \\
\text { before by }\end{array}$} & \multicolumn{4}{|c|}{ Estimated AADT } & \multicolumn{2}{|c|}{$\begin{array}{l}\text { Number of } \\
\text { months }\end{array}$} & \multirow{3}{*}{ 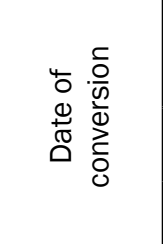 } & \multicolumn{4}{|c|}{$\begin{array}{c}\text { Number of crashes } \\
(2005-2013)\end{array}$} \\
\hline & & & \multicolumn{2}{|c|}{ Before } & \multicolumn{2}{|c|}{ After } & \multirow{2}{*}{$\begin{array}{l}0 \\
\frac{0}{0} \\
\frac{0}{0}\end{array}$} & \multirow{2}{*}{$\underset{\frac{\Phi}{4}}{\frac{ \pm}{4}}$} & & \multicolumn{2}{|c|}{ Before } & \multicolumn{2}{|c|}{ After } \\
\hline & & & Main & Minor & Main & Minor & & & & All & Injury & All & Injury \\
\hline A & 3 & Traffic signs & 5,189 & 1,044 & 5,307 & 1,068 & 23 & 109 & Nov. 2005 & 1 & 0 & 1 & 0 \\
\hline $\mathrm{B}$ & 3 & Traffic signs & 3,891 & 1,001 & 3,976 & 1,021 & 71 & 61 & Nov. 2009 & 1 & 0 & 0 & 0 \\
\hline$C$ & 3 & Traffic signs & 7,567 & 57 & 7,733 & 58 & 55 & 77 & Aug. 2008 & 1 & 0 & 1 & 0 \\
\hline $\mathrm{D}$ & 3 & Traffic signs & 7,709 & 411 & 7,879 & 420 & 63 & 69 & Mar. 2009 & 0 & 0 & 2 & 1 \\
\hline$E$ & 3 & Traffic lights & 22,458 & 9,972 & 22,807 & 10,121 & 94 & 38 & Oct. 2011 & 51 & 8 & 2 & 0 \\
\hline $\mathrm{F}$ & 3 & Traffic lights & 12,699 & 4,091 & 12,889 & 4,152 & 68 & 64 & Aug. 2009 & 2 & 1 & 1 & 0 \\
\hline $\mathrm{G}$ & 3 & Traffic signs & 5,221 & 1,596 & 5,229 & 1,602 & 119 & 13 & Nov. 2013 & 7 & 2 & 1 & 1 \\
\hline $\mathrm{H}$ & 4 & Traffic lights & 7,391 & 3,889 & 7,568 & 3,975 & 57 & 75 & Sep. 2008 & 3 & 1 & 2 & 1 \\
\hline I & 4 & Traffic signs & 7,567 & 302 & 7,733 & 309 & 55 & 77 & Aug. 2008 & 0 & 0 & 2 & 0 \\
\hline J & 4 & Traffic signs & 7,892 & 978 & 8,005 & 990 & 68 & 64 & Aug. 2009 & 1 & 0 & 1 & 0 \\
\hline $\mathrm{K}$ & 4 & Traffic signs & 20,670 & 18,573 & 20,980 & 18,851 & 71 & 61 & Nov. 2009 & 2 & 0 & 3 & 0 \\
\hline $\mathrm{L}$ & 4 & Traffic signs & 3,542 & 1,133 & 3,612 & 1,154 & 78 & 54 & Jun 2010 & 1 & 0 & 1 & 0 \\
\hline $\mathrm{M}$ & 4 & Traffic lights & 23,061 & 12,603 & 23,406 & 12,792 & 102 & 30 & Jun 2012 & 65 & 16 & 5 & 2 \\
\hline $\mathrm{N}$ & 4 & Traffic signs & 23,003 & 18,262 & 23,348 & 18,536 & 102 & 30 & Jun 2012 & 49 & 14 & 5 & 3 \\
\hline 0 & 4 & Traffic lights & 7,900 & 5,221 & 7,922 & 5,229 & 118 & 14 & Oct. 2013 & 10 & 2 & 1 & 1 \\
\hline
\end{tabular}

number of crashes which happen in the period after the conversion.

$\delta=\pi-\lambda$

$\operatorname{Var}(\delta)=\operatorname{Var}(\lambda)+\operatorname{Var}(\pi)$

The number of crashes before treatment is not a good estimate of $\pi$ due to changes in safety that may result from regression-to-the-mean or changes in traffic volume. So, instead of that, $\pi$ is estimated by using EB procedure where Safety Performance Function (SPF) is used for estimation of the number of crashes at intersections similar to those which are being analyzed $P$ [1]. These control intersections are similar to the analyzed ones in terms of similar geometry (Table 3), often

Table 3 - Intersection's basic geometric elements

\begin{tabular}{|c|c|c|c|c|c|c|}
\hline $\begin{array}{c}\text { Intersection's } \\
\text { ID } \\
\end{array}$ & $\begin{array}{c}\text { Inscribed circle } \\
\text { diameter ICD [m] }\end{array}$ & $\begin{array}{c}\text { Circulatory lane } \\
\text { width }[\mathrm{m}]\end{array}$ & $\begin{array}{l}\text { Entry lane } \\
\text { width }[\mathrm{m}]\end{array}$ & $\begin{array}{l}\text { Exit lane width } \\
{[\mathrm{m}]}\end{array}$ & $\begin{array}{c}\text { Entry radius } \\
{[\mathrm{m}]}\end{array}$ & $\begin{array}{c}\text { Exit radius } \\
{[\mathrm{m}]}\end{array}$ \\
\hline$A$ & 35 & 4.5 & 3.5 & 3.5 & 12 & 15 \\
\hline$B$ & 35 & 4.5 & 3.5 & 3.5 & 12 & 15 \\
\hline C & 35 & 4.5 & 3.5 & 3.5 & 12 & 15 \\
\hline$D$ & 35 & 4.5 & 3.5 & 3.5 & 12 & 15 \\
\hline $\mathrm{E}$ & 38 & 4.5 & 3.5 & 3.5 & 12 & 15 \\
\hline$F$ & 38 & 4.5 & 3.5 & 3.5 & 12 & 15 \\
\hline $\mathrm{G}$ & 35 & 4.5 & 3.5 & 3.5 & 12 & 15 \\
\hline $\mathrm{H}$ & 38 & 4.5 & 3.5 & 3.5 & 12 & 15 \\
\hline 1 & 35 & 4.5 & 3.5 & 3.5 & 12 & 15 \\
\hline $\mathrm{J}$ & 35 & 4.5 & 3.5 & 3.5 & 12 & 15 \\
\hline $\mathrm{K}$ & 38 & 4.5 & 3.5 & 3.5 & 12 & 15 \\
\hline $\mathrm{L}$ & 35 & 4.5 & 3.5 & 3.5 & 12 & 15 \\
\hline$M$ & 38 & 4.5 & 3.5 & 3.5 & 12 & 15 \\
\hline $\mathrm{N}$ & 38 & 4.5 & 3.5 & 3.5 & 12 & 15 \\
\hline 0 & 35 & 4.5 & 3.5 & 3.5 & 12 & 15 \\
\hline
\end{tabular}


with the same main road, and the same speed limit - $50 \mathrm{~km} / \mathrm{h}$. Data about control intersections are given in Table 4. For the estimation of the number of crashes at intersections similar to those which are being analyzed, a method similar to [22-24] was used, which is shown in Equation 3. Parameters $\alpha, \beta_{1}$ and $\beta_{2}$ are estimated in the model calibration process, separately for both 3-legged and 4-legged intersections, and separately for all crashes and for the crashes with injuries.

$P\left(\frac{\text { accident }}{\text { year }}\right)=(\alpha)\left(A A D T_{\text {main road }}\right)^{\beta 1}\left(A A D T_{\text {minor road }}\right)^{\beta 2}(3)$

In essence, a regression model is used to first estimate the annual number of crashes $P$ that would be expected at intersections with traffic volumes and other characteristics similar to the one being analyzed. The regression estimate is then combined with the number of crashes $\left(x_{b}\right)$ which happen in $\left(y_{b}\right)$ years before the conversion in order to get an expected annual number of crashes $\left(m^{b}\right)$ at the intersection before conversion. This estimate of $m$ is (Equation 4):

$m_{b}=w_{1}\left(x_{b}\right)+w_{2}(P)$

where the weights $w_{1}$ and $w_{2}$ are estimated from the mean and variance of the regression estimate as (Equations 5 and 6):

$w_{1}=\frac{P}{\left(k+y_{b} P\right)}$

Table 4 - Control intersections data

\begin{tabular}{|c|c|c|c|c|c|c|}
\hline \multirow[t]{2}{*}{ Intersection } & \multirow{2}{*}{$\begin{array}{l}\text { Number of } \\
\text { approaches }\end{array}$} & \multirow[t]{2}{*}{ Controlled by } & \multicolumn{2}{|c|}{ AADT } & \multicolumn{2}{|c|}{$\begin{array}{c}\text { Annual average } \\
\text { number of crashes }\end{array}$} \\
\hline & & & Main & Minor & All & Injury \\
\hline 1 & 3 & Traffic signs & 8,044 & 1,002 & 0.27 & 0.09 \\
\hline 2 & 3 & Traffic lights & 12,841 & 2,411 & 0.36 & 0.18 \\
\hline 3 & 3 & Traffic lights & 9,287 & 2,432 & 0.18 & 0.09 \\
\hline 4 & 3 & Traffic signs & 12,782 & 1,596 & 0.45 & 0.18 \\
\hline 5 & 3 & Traffic lights & 12,730 & 2,121 & 0.45 & 0.18 \\
\hline 6 & 3 & Traffic signs & 8,608 & 1,214 & 0.18 & 0.09 \\
\hline 7 & 3 & Traffic signs & 7,854 & 317 & 0.00 & 0.00 \\
\hline 8 & 3 & Traffic lights & 12,261 & 742 & 0.18 & 0.09 \\
\hline 9 & 3 & Traffic lights & 23,001 & 4,238 & 0.55 & 0.27 \\
\hline 10 & 3 & Traffic lights & 12,612 & 3,894 & 0.36 & 0.18 \\
\hline 11 & 3 & Traffic signs & 12,454 & 4,446 & 0.27 & 0.09 \\
\hline 12 & 3 & Traffic signs & 9,047 & 1,470 & 0.18 & 0.00 \\
\hline 13 & 3 & Traffic lights & 10,225 & 2,656 & 0.18 & 0.09 \\
\hline 14 & 3 & Traffic signs & 12,600 & 3,969 & 0.36 & 0.18 \\
\hline 15 & 3 & Traffic signs & 12,600 & 3,086 & 0.18 & 0.09 \\
\hline 16 & 4 & Traffic lights & 21,103 & 16,462 & 0.91 & 0.36 \\
\hline 17 & 4 & Traffic lights & 22,458 & 13,942 & 0.82 & 0.18 \\
\hline 18 & 4 & Traffic lights & 22,511 & 11,683 & 0.64 & 0.18 \\
\hline 19 & 4 & Traffic signs & 8,465 & 4,622 & 0.45 & 0.18 \\
\hline 20 & 4 & Traffic signs & 9,112 & 4,856 & 0.45 & 0.00 \\
\hline 21 & 4 & Traffic signs & 13,940 & 6,532 & 0.55 & 0.09 \\
\hline 22 & 4 & Traffic lights & 18,448 & 8,674 & 0.36 & 0.18 \\
\hline 23 & 4 & Traffic signs & 10,854 & 3,054 & 0.45 & 0.18 \\
\hline 24 & 4 & Traffic signs & 10,892 & 4,212 & 0.55 & 0.18 \\
\hline 25 & 4 & Traffic signs & 12,702 & 1,098 & 0.36 & 0.18 \\
\hline 26 & 4 & Traffic signs & 7,556 & 3,821 & 0.27 & 0.00 \\
\hline 27 & 4 & Traffic lights & 6,784 & 3,221 & 0.18 & 0.18 \\
\hline 28 & 4 & Traffic lights & 6,820 & 4,385 & 0.27 & 0.09 \\
\hline 29 & 4 & Traffic signs & 5,902 & 2,658 & 0.18 & 0.18 \\
\hline 30 & 4 & Traffic lights & 14,860 & 7,532 & 0.55 & 0.27 \\
\hline
\end{tabular}


$w_{2}=\frac{k}{\left(k+y_{b} P\right)}$

where $k$ is the over-dispersion parameter of negative binomial distribution, which relates the mean and variance [25].

For the estimation of the number of crashes which would typically happen at intersections in the period after conversion in one year (12 months) if an intersection had not been converted into a roundabout $m_{a}$ (Equation 8), the period after conversion has to be taken into consideration, as well as the difference in AADT, where, first, $P_{a}$ (Equation 3 ) is calculated, and then the relation - $R$ between $P_{a}$ and $P_{b}$ - average annual number of crashes after and before conversion (Equation 7) [22-24].

$R=\frac{P_{a}}{P_{b}}$

$m_{a}=R \cdot m_{b}$

In the end, the total expected number of crashes which would happen in the period after the conversion if the intersection was not converted into a roundabout is obtained $B$. It is obtained by using Equation 9, where $y_{a}$ is the number of the years after the conversion [2224].

$B=m_{a} \cdot y_{a}$

If $A$ is the number of crashes which happen at an intersection after the conversion and $B$ is the expected number of crashes which happen at the intersection in the period after the conversion if the intersection was not converted into a roundabout, then [22-24]:

$\Pi=\Sigma B$

$\operatorname{Var}(\pi)=\Sigma \operatorname{Var}(B)$

$\lambda=\Sigma A$

The effectiveness of conventional intersection conversion into roundabouts can be shown best by the index of safety effectiveness $\theta$ which is calculated by Equation 13 [22-24].

$\theta=\frac{\left(\frac{\lambda}{\pi}\right)}{\left(1+\left(\frac{\operatorname{Var}(\pi)}{\pi^{2}}\right)\right)}$

As an absolute indicator of safety differences between conventional intersections and roundabouts, $\delta$ can be used - the difference between the number of crashes which could be expected at intersections in the period after the conversion if they were not converted into roundabouts and the number of crashes which happen in that period [22-24].

However, two indicators are typically considered to be the best in terms of showing the effects that conventional intersection conversion into roundabouts has for traffic safety [12]. The first one is the index of safety effectiveness $\theta$, which is approximately equal to the relation between the number of crashes which happened in the period after the conversion and the number of crashes which could have been expected at intersections in the period after conversion if they had not been converted into roundabouts. The second indicator, the most conventional one, is the percentage of difference, i.e. percentage of decrease of the number of crashes which is calculated according to Equation 14 [22-24].

$\%$ of difference $=100 \cdot(1-\theta)$

\section{RESULTS}

In the city of Niš, 15 intersections were identified which had been converted from conventional intersections to roundabouts in the period from 2005 to 2013. Data on all the intersections are summarized in Table 2. Estimated AADT is average AADT for the observed period before/after. Period "after" includes data for the year 2014 as well.

First, SPF is used for the estimation of the number of crashes similar to the intersections which are being analyzed. By the regression analysis, parameters are estimated separately for 3-legged and 4-legged intersections, separately for all crashes and separately for injury crashes, which are shown in Table 5.

By using the rest of the procedure, other parameters are calculated which are necessary for the estimation of the number of total crashes that would have happened at each intersection if they had not been converted into a roundabout.

For all intersections, the index of safety effectiveness is estimated to be 0.24 for all crashes and 0.20 for injury crashes. This means that the decrease of crashes is estimated at all analyzed intersections to be around $76 \%$ for all crashes, and around $80 \%$ for injury crashes (Table 6).

Table 5 - Parameter estimates for SPFs

\begin{tabular}{||c|c|c|c|c|c||}
\hline \hline Type of ntersection & Crash type & $\alpha$ & $\beta_{1}$ & $\beta_{2}$ & $k$ \\
\hline \hline \multirow{2}{*}{ 3-legged } & all crashes & 0.000004 & 0.691 & 0.095 & 4.70 \\
\cline { 2 - 6 } & injury crashes & 0.000002 & 0.696 & 0.073 & 4.82 \\
\hline \multirow{2}{*}{ 4-legged } & all crashes & 0.000003 & 0.331 & 0.561 & 5.80 \\
\cline { 2 - 6 } & injury crashes & 0.000049 & 0.010 & 0.481 & 5.57 \\
\hline
\end{tabular}


M. Vujanić, et al.: Safety Effectiveness of Converting Conventional Intersections to Roundabouts: Case Study in the City of Niš

Table 6 - Summary results of conversion effectiveness of different types of intersections

\begin{tabular}{|c|c|c|c|c|c|c|}
\hline & \multicolumn{3}{|c|}{ All } & \multicolumn{3}{|c|}{ Injury } \\
\hline & \multirow[t]{2}{*}{$\theta$} & \multicolumn{2}{|c|}{$\begin{array}{l}\text { 95\% confidence interval of the } \\
\text { difference }\end{array}$} & \multirow[t]{2}{*}{$\theta$} & \multicolumn{2}{|c|}{$\begin{array}{l}\text { 95\% confidence interval of the } \\
\text { difference }\end{array}$} \\
\hline & & Lower bound & Upper bound & & Lower bound & Upper bound \\
\hline All intersections & 0.24 & 0.28 & 0.15 & 0.20 & 0.21 & 0.05 \\
\hline 3-legged & 0.16 & 0.26 & 0.07 & 0.09 & 0.15 & -0.01 \\
\hline 4-legged & 0.30 & 0.33 & 0.19 & 0.28 & 0.31 & 0.06 \\
\hline Traffic signs & 0.28 & 0.33 & 0.15 & 0.20 & 0.21 & 0.05 \\
\hline Traffic lights & 0.19 & 0.21 & 0.13 & 0.19 & 0.33 & 0.02 \\
\hline 3-legged/Traffic signs & 0.21 & 0.32 & 0.05 & 0.14 & 0.20 & -0.01 \\
\hline 3-legged/Traffic lights & 0.11 & 0.18 & 0.07 & 0.00 & 0.00 & 0.00 \\
\hline 4-legged/Traffic signs & 0.33 & 0.39 & 0.21 & 0.23 & 0.28 & -0.02 \\
\hline \multirow[t]{3}{*}{ 4-legged/Traffic lights } & 0.25 & 0.23 & 0.17 & 0.31 & 0.45 & 0.13 \\
\hline & \multirow{2}{*}{$\begin{array}{c}\% \text { of } \\
\text { difference }\end{array}$} & \multicolumn{2}{|c|}{$\begin{array}{l}\text { 95\% confidence interval of the } \\
\text { difference }\end{array}$} & \multirow{2}{*}{$\begin{array}{c}\% \text { of } \\
\text { difference }\end{array}$} & \multicolumn{2}{|c|}{$\begin{array}{l}\text { 95\% confidence interval of the } \\
\text { difference }\end{array}$} \\
\hline & & Lower bound & Upper bound & & Lower bound & Upper bound \\
\hline All intersections & 75.98 & 71.91 & 84.67 & 79.89 & 78.65 & 95.06 \\
\hline 3-legged & 83.99 & 73.54 & 93.39 & 90.98 & 85.22 & 101.39 \\
\hline 4-legged & 70.29 & 66.93 & 80.58 & 72.21 & 68.82 & 93.60 \\
\hline Traffic signs & 71.65 & 66.95 & 84.93 & 80.27 & 79.85 & 98.14 \\
\hline Traffic lights & 80.89 & 78.80 & 87.17 & 80.71 & 66.78 & 98.37 \\
\hline 3-legged/Traffic signs & 79.02 & 68.45 & 95.47 & 85.78 & 80.20 & 101.07 \\
\hline 3-legged/Traffic lights & 89.01 & 81.88 & 92.56 & 100.00 & 100.00 & 100.00 \\
\hline 4-legged/Traffic signs & 67.35 & 60.69 & 79.15 & 76.93 & 72.47 & 102.25 \\
\hline 4-legged/Traffic lights & 75.10 & 76.93 & 83.38 & 69.33 & 54.80 & 87.11 \\
\hline
\end{tabular}

The effectiveness of 3-legged intersection conversion was examined separately, and the 4-legged one as well. At 3-legged intersections, $\theta$ is 0.16 for all crashes, and 0.09 for injury crashes. This means that, at these intersections, the decrease of crashes is estimated to account for around $84 \%$ of all crashes, and around $91 \%$ of injury crashes. The effectiveness index of 0.30 is calculated for all crashes at 4-legged intersections, and 0.28 for the injury crashes. This means that at 4-legged intersections the decrease of total crashes is estimated to be around $70 \%$, and the decrease in the number of injury crashes to be around $72 \%$ (Table 6).

The safety effects of roundabout installation on intersections previously controlled by traffic signs were more closely examined. The effectiveness of the conversion is separately examined for intersections, at which, before the conversion, traffic was controlled by traffic lights. At intersections, where before the conversion the traffic was controlled by traffic signs, the index of safety effectiveness was calculated and it is 0.28 for all crashes, and 0.20 for injury crashes. This means that, at these intersections, the decrease of total number of crashes is around $72 \%$, and the number of injury crashes is around $80 \%$. At intersections, where before the conversion traffic was managed by traffic lights, the index of safety effectiveness is 0.19 for all crashes, as well as for the injury crashes. This means that, at these intersections, the decrease of the total number of crashes as well as the injury crashes is estimated to be around $81 \%$. The effects of conversion of different combination of the above mentioned types of intersections were also analyzed. Summary results are given in Table 6.

\section{DISCUSSION}

The results of this research show that the conversion of conventional intersections into roundabouts can have a significant decrease of crashes as a result. Different studies have shown a decrease in the number of crashes (especially those with the injured). The percent of decrease differs from study to study. When comparing results of this research with the results of previous studies done in the world which used EB method, it can be concluded that the reduction of crashes with injured shown in this paper is in accordance with several studies shown in [4] and [12], and it is closest to those obtained in France and in the USA. On the other hand the percent of overall crash reduction is lower in previous studies done in 
the western European countries, USA and Australia in comparison with the results of this research. Although there are differences between these regions, too (e.g. in the USA - 35\% and in Australia up to $61 \%$ of crash reduction), it can be possible that in the south-eastern part of Europe this reduction is bigger. Unfortunately, there is no research which has ever been done in Serbia or in any of the neighbouring countries to compare these type of results, which presents a limitation on this paper. One of the major problems because this kind of research has never been previously conducted is missing of some data entries (primarily about traffic accidents and AADT). In this particular research, the collection of data was not much of a problem but, in general, this is often the major limitation of conducting any traffic safety research.

It should also be noted that this study was limited to 15 intersections, which were converted into large compact two-lane roundabouts in the city of Niš. Although similar results with some previous studies have been shown in the world [4] and [12], the results of this study should be examined with caution because of the limited number of case study roundabouts and may still yet need to be proven after further research in the cites within Serbia as well as the rest of the region.

Numerous studies have shown that the conversion does not give the same results for the different types of intersections. In this way, it is shown that the conversion has been more effective at 3-legged than at 4-legged intersections.

On the one hand, these results are quite surprising due to the fact that the reduction of conflict points after the conversion is more significant at 4-legged (from 32 to 8) than at 3-legged intersections (from 9 to 6). But on the other hand it could be possible that there is significantly lower crash risk at 3-legged roundabouts than at 4-legged roundabouts i.e. that the correlation between decrease of crashes and reduction of conflict points is not linear. It can be also stated that at 3-legged roundabouts (marked as C and D), all crashes that occurred in the period after the conversion were due to vehicle's overrunning the central island (by traffic police data), which do not have direct link with conflict points. Simodines et al. [28] examined a correlation between reduction of conflict points and crash occurrence but they did not find a clear relationship between the reduction of conflict points and the expected crash reduction. This can be the subject of further research, where correlation between reduction of conflict points and crash occurrence can be examined. The results of such research may be helpful in better understanding of the results obtained in this study.

The results of the research also indicate that the effects of conversion are more significant at intersections which were managed by traffic lights before the conversion than at the ones where the traffic was regulated by the traffic signs. These results may be explained by the fact that traffic lights usually correspond with intersections with high AADT or with intersections with higher crash rate because traffic lights contribute greatly in assisting drivers to negotiate an intersection, more so than sign-controlled intersections. This means that most of the intersections with high crash rate were controlled by traffic lights, and because of that the reduction of all crashes after the conversion is more significant at intersections with traffic lights than at sign-controlled intersections.

If the effects of different combinations of intersections are analyzed, it can be concluded that the conversion has been most effective in 3-legged intersections which were managed by traffic lights.

In this research the EB method for observational studies before and after was used. The EB method has a number of advantages such as that it properly accounts for regression-to-the-mean, overcomes the difficulties of using crash rates in normalizing for volume differences between the before and after periods, and provides bigger reliability in effect determination for the safety, especially when grouping of different intersections according to certain criteria [1]. There is general consensus among researchers and practitioners regarding the superiority of EB technique, and it is recommended for use in all circumstances where the data and required SPFs are available [31]. The usage of other methods would give less reliable results, because other methods (e.g. naive before-and-after method) are usually unable to separate the conversion effect from other effects, and these results may typically be affected by regression-to-mean bias [32].

\section{CONCLUSION}

The main aim of this paper was to show roundabouts effectiveness in terms of traffic safety i.e. in reduction of crashes. The aim was not just to show the overall results in safety effectiveness of converting intersections in to roundabouts, but also to show the effects that conversion of different type of intersections into roundabouts has on traffic safety. Safety effectiveness of roundabouts was determined by using EB method, which can be used for this and further similar research.

Study results and the results of numerous studies done throughout the world show that the effects of conventional intersection conversion into roundabouts are positive for traffic safety. In the city of Niš, the decrease of the number of crashes is estimated to be around $76 \%$ for all crashes, and around $80 \%$ for injury crashes, and the conversion shows the best effects at 3-legged intersections which had been 
regulated by the traffic lights before the conversion. The conclusions with regard to this kind of research have for the result the fact that some authors suggest the conversion of conventional intersections into roundabouts as rehabilitation measures of black spots [27], because they lead to a decrease in the number of injury crashes.

It is also important to know how substantial are the effects that conversion of different type of intersections into roundabouts have on traffic safety. Funds for the conversion of all intersections that are planned to be converted into roundabouts on a traffic network are usually insufficient, and to ensure the proper allocation of resources intended for this purposes it is of great importance to clearly know on which intersections conversion would have the best effects. Proper identification of such places is also required as one of the elements for defining road safety strategy in a given area [30]. Establishing the procedure is the main task of the future studies by which it would be determined how substantial the effects of conventional intersection conversion into roundabouts would be, concerning traffic safety.



\section{EFEKTIVNOST ZAMENE KLASIČNIH RASKRSNICA KRUŽNIM RASKRSNICAMA SA ASPEKTA BEZBEDNO- STI SAOBRAĆAJA - STUDIJA SLUČAJA U GRADU NIŠU}

\section{REZIME}

Raskrsnice predstavljaju veliki bezbednosni problem u saobraćaju s obzirom da je na njima povećan rizik od nastanka saobraćajnih nezgoda usled konflikata prilikom ukrštanja saobraćajnih tokova. Brojne studije rađene u svetu ukazuju da su kružne raskrsnice bezbednije od klasičnih raskrsnica sa direktnim ukrštanjem tokova s obzirom da je na njima zabeleženo smanjenje broja saobraćajnih nezgoda. U ovom radu sprovedeno je istraživanje primenom empirijskog Bajesovog metoda u kojem je na primeru 15 dvotračnih raskrsnica u gradu Nišu, koje su u periodu 2005.-2013. konvertovane u kružne, pokazano da konverzija klasičnih raskrsnica u kružne ima pozitivne efekte u pogledu smanjenja broja saobraćajnih nezgoda. Na svim analiziranim raskrsnicama procenjeno je ukupno smanjenje broja saobraćajnih nezgoda od $76 \%$ za sve saobraćajne nezgode, odnosno $80 \%$ za saobraćajne nezgode sa nastradalim licima. Za određene grupe raskrsnica su efekti utvrđivani posebno.

\section{KLUČNE REČI}

efektivnost u bezbednosti saobraćaja; kružne raskrsnice; empirijski Bajesov metod;

\section{REFERENCES}

[1] Gross F, Lyon C, Persaud B, Srinivasan R. Safety effectiveness of converting signalized intersections to roundabouts. Accident Analysis and Prevention. 2013;50:234-241.

[2] raffic Safety Agency. Statistical traffic safety report in the Republic of Serbia in 2012 [in Serbian]. Belgrade: Traffic Safety Agency; 2013.

[3] Thai Van M, Balmefrezol P. Design of roundabouts in France. Transportation Research Record. 2013;1737:92-97.

[4] Rodegerdts L, Bansen J, Tiesler C, Knudsen J, Myers E. Roundabouts: An informational gude. Report 672 - Second Edition. Transportation Research Board - National Cooperative Highway Research Program. Washington DC, USA; 2010.

[5] Pellecuer L, St-Jaques M. Last advance about roundabouts. Canadian Journal of Civil Engineering. 2008;35:542-553.

[6] Sacchi E, Bassani M, Persaud B. Comparison of Safety Performance Models for Urban Roundabouts in Italy and Other Countries. Transportation Research Record. 2011;2265:253-259.

[7] Sangyoup K, Jaisung C. Safety Analysis of Roundabout Designs based on Geometric and Speed Characterisitcs, KSCE Journal of Civil Engineering. 2013;17(6):1446-1454.

[8] Pilko H, Brčić D, Šubić N. Study of vehicle speed in the design of roundabouts. Građevinar. 2014;66(5):407416.

[9] Schoon C, Van Minnen J. Accidents at roundabouts II: Second investigation into the safety of roundabouts especially for cyclists and moped riders [in Dutch]. Stichting Wetenschappelijk Onderzoek Verkeersveiligheid (SWOV), rapport R-93-16. Leidschendam; 1993.

[10] Institute of Transportation Engineers-ITE. Traffic Safety Toolbox: A Primer on Traffic Safety. Washington DC, USA: Institute of Transportation Engineers; 1999.

[11] Hyden C, Varhelyi A. The effects on safety time consumption and environment of large scale use of roundabouts in an urban area: a case study. Accident Analysis and Prevention. 2000;32(1):11-23.

[12] Persaud B, Retting R, Garder P, Lord D. Safety effects of roundabout conversions in the United States: empirical Bayes observational before-and-after study. Transportation Research Record. 2001;1751:1-8.

[13] Elvik R. Effects on road safety of converting intersections to roundabouts: review of evidence from Non-U.S. studies. Transportation Research Record. 2003;1847:1-10.

[14] De Brabander B, Vereeck L. Safety effects of roundabouts in Flanders: Signal type, speed limits and vulnerable road users. Accident Analysis and Prevention. 2007;39(3):591-599.

[15] Daniels S, Brijs T, Nuyts E, Wets G. Explaining variation in safety performance of roundabouts. Accident Analysis and Prevention. 2010;42(2):393-402. 
[16] Hels T, Orozova-Bekkevold I. The effect of roundabout design features on cyclist accident rate. Accident Analysis and Prevention. 2007;39(2):300-307.

[17] Stone J R, Chae K, Pillalamarri S. The effects of roundabouts on pedestrian safety. Southeastern Transportation Center, working paper. Tenessee, USA; 2002.

[18] Candappa N, Stephan K, Corben B. Raised crosswalks on entrance to the roundabout-a case study on effectiveness of treatment on pedestrian safety and convenience. Traffic Injury Prevention. 2014;15(6):631-639.

[19] Senica G, Milosevic M. Modern roundabouts - planning process. Project Institute, Belgrade; 2002.

[20] Brüde U, Larsson J. What roundabout design provides the highest possible safety? Nordic Road Transport Res. 2000;12(2):17-21.

[21] Hauer E. Observational Before-After Studies in Road Safety: Estimating the Effect of Highway and Traffic Engineering Measures on Road Safety. Pergamon Press, Oxford, UK; 1997.

[22] Bonneson J, Mc Coy P. Estimation of safety at twoway STOP-controlled intersections on rural highways. Transportation Research Record. 1993;1401:83-89.

[23] Vogt A, Bared J. Accident models for two lane rural segments and intersections. Transportation Research Record. 1998;1635:18-29.

[24] Hauer E, Harwood D W, Council F M, Griffith M S. Estimating Safety by the Empirical Bayes Method. Trans portation Research Record. 2002;1784:126-131.

[25] Zhang Y, Ye Z, Lord D. Estimating the Dispersion Parameter of the Negative Binomial Distribution for Analyzing Crash Data Using a Bootstraped Maximum Likelihood Method. Transportation Research Record. 2007;2019:15-21.
[26] Vujanić M, Antić B, Pešić D, Savićević M. Application of objective methods for black spot identification and classification. XIII International Conference Road Safety in Local Communities; 2013 April 18-20; Divčibare, Serbia; 2013.

[27] Geurts K, Thomas I, Wets G. Understanding spatial concentrations of road accidents using frequent item sets. Accident Analysis and Prevention. 2005;37(4):787799.

[28] Simodines T, Welch T, Kuntemeyer M. Effects of Reducing Conflict Points on Reducing Accidents. Third National Access Management Conference. Fort Lauderdale, Florida, USA; 2001.

[29] Bared J.G., Kennedy K. Safety Impacts of Modern Roundabouts, Chapter 28, the Traffic Safety Toolbox: A Primer on Traffic Safety. Institute of Transportation Engineers; 2000.

[30] Vujanić M, Lipovac K, Jovanović D, Pešić D, Antić B. "Bottom-up" and "top-down" approach for defining road safety strategy - case study: City of Belgrade. International Journal for Traffic and Transport Engineering. 2013;3(2):185-203.

[31] Institute of Transportation Engineers - ITE. Before-and-after study. Technical brief. Washington DC, USA: Institute of Transportation Engineers; 2009.

[32] Mun S, Lee Y. The Comparison Study on Observational Before-After Studies: Case Study on Safety Evaluation on Highways. Journal of Korean Society of Transportation. 2013;31(6):67-89.

[33] Brilon, W. Studies on Roundabouts in Germany: Lessons Learned, $3^{\text {rd }}$ International TRB-roundabout Conference; 2011 May 18-20; Carmel, Indiana; 2011. 